Tjalling C. Koopmans Research Institute Thlligh Roopmen

Discussion Paper Series nr: 09-29

\title{
AN EXPERIMENTAL STUDY INTO THE INFLUENCE OF WORKS COUNCIL ADVICE ON MANAGERIAL DECISION-MAKING
}

Saraï Sapulete

Arjen van Witteloostuijn

Wesley Kaufmann 


\title{
Tjalling C. Koopmans Research Institute Utrecht School of Economics \\ Utrecht University
}

Janskerkhof 12

3512 BL Utrecht

The Netherlands

telephone $\quad+31302539800$

fax +31302537373

website www.koopmansinstitute.uu.nl

The Tjalling C. Koopmans Institute is the research institute and research school of Utrecht School of Economics.

It was founded in 2003, and named after Professor Tjalling C. Koopmans, Dutch-born Nobel Prize laureate in economics of 1975.

In the discussion papers series the Koopmans Institute publishes results of ongoing research for early dissemination of research results, and to enhance discussion with colleagues.

Please send any comments and suggestions on the Koopmans institute, or this series to J.M.vanDort@uu.nl

ontwerp voorblad: WRIK Utrecht

\author{
How to reach the authors \\ Please direct all correspondence to the first author. \\ Saraï Sapulete ${ }^{a}$ \\ Arjen van Witteloostuijn ${ }^{\text {ab }}$ \\ Wesley Kaufmann ${ }^{\text {b }}$ \\ aUtrecht University \\ Utrecht School of Economics \\ Janskerkhof 12 \\ 3512 BL Utrecht \\ The Netherlands. \\ E-mail: s.sapulete@uu.nl \\ bUniversity of Antwerp \\ Management department \\ Stadscampus \\ Kipdorp 61 \\ 2000 Antwerpen \\ E-mail: Arjen.vanWitteloostuijn@ua.ac.be \\ E-mail:Wesley.Kaufmann@ua.ac.be
}




\title{
AN EXPERIMENTAL STUDY INTO THE INFLUENCE OF WORKS COUNCIL ADVICE ON MANAGERIAL DECISION-MAKING
}

\author{
Saraï Sapulete \\ Arjen van Witteloostuijn ${ }^{\text {ab }}$ \\ Wesley Kaufmann ${ }^{b}$ \\ aUtrecht School of Economics \\ Utrecht University \\ ${ }^{\mathrm{b}}$ Management department \\ University of Antwerp
}

October 2009

\begin{abstract}
This paper experimentally studies the potential effect of works councils on managerial decision-making. Empirical evidence on the influence of works councils in organizations is still mixed. Therefore, this experimental study tries to gain more insights into the mechanisms that may underlie the impact of works council advice. First, we try to explain whether advice given by a works council influences the decision managers make. Second, we attempt to explain whether works councils delay the decision-making process. In order to answer these questions, we conducted experiments with undergraduate students, who played a two-player Prisoner's Dilemma price-setting game. One group received advice from a works council, whilst the other group did not. As expected, advice does have an influence on decision-making: receiving advice for setting a low price leads to a higher likelihood to set a low price as well, and receiving advice to set a high price leads to a high price decision. Female managers are more likely to take the works council advice into account. Subjects with an other-regarding orientation tend to choose a high price, even when they are advised to opt for a low price. Further, decisionmaking is not delayed by the advice, but there is an interaction effect with gender: female managers receiving advice tend to think longer about their decision.
\end{abstract}

Keywords: works council advice, experimental economics, managerial decisionmaking

JEL classification: J53, C91, L29

\section{Acknowledgements}

We would like to thank Stephanie Rosenkranz and Vincent Buskens for using the ELSE laboratory, as well as for their valuable comments on programming and the ins and outs of experimental economics. We are grateful to Jan Potters for his helpful comments regarding the content of the paper. Furthermore, we would like to thank our colleagues who helped us out with the pilot experiment. Wesley Kaufmann and Arjen van Witteloostuijn gratefully acknowledge the financial support from the Odysseus program of the Flemish Science Foundation (FWO). 


\section{INTRODUCTION}

Managerial decision-making is an important topic in the organizational literature. Manager's decisions are critical for the overall performance of an organization. Therefore, the way managers make their decisions is a topic of interest to many in the field or organization sciences. Clearly, a large number of factors can influence managerial decision-making, such as the history of the organization, the economic position of the organization and characteristics of the decision-maker, but also the opinions of other parties such as employees and shareholders. This paper focuses on the latter type of influence - i.e., the influence of employee voice on managerial decision-making. We do so in an experimental study with Dutch university students, seeking to unravel some of the mechanisms underlying the impact of codetermination on managerial decisions. Of course, such an experimental design implies a stylized representation of reality. However, we believe this is a justified methodological choice in an attempt to deepen our understanding of the fundamental processes associated with the employee-manager interaction that is central to codetermination.

Employees can organize themselves in several ways. Well-known cases of formal codetermination arrangements are works councils as established by law in Germany and the Netherlands. In the Netherlands, for example, organizations are obliged to have a works council when they employ more than 50 employees. By law, Dutch works councils operate in the interest of the organization as a whole, including employees and shareholders. They have several legal rights, such as the right of being informed on relevant matters in the organization (right of information), the right to give advice on organizational matters (right of consultation), and the right of approval on certain issues (right of consent) (van den Berg, Grift, \& van Witteloostuijn, 2008a). The current paper mainly focuses on the right of consultation, which is the legal right to give advice to the management team on a wide variety of organizational matters.

Research has not yet succeeded in agreeing upon the influence of works councils on organizational decision-making and performance. Many empirical studies relate to Germany. For example, Addison, Schnabel and Wagner (2001) find a positive effect on the organization's productivity, but a negative impact on profitability. Wever (1994) compares five cases, and reports that, overall, works councils can make effective strategic choices, and hence can be beneficial to 
management. In a first econometric study in the Netherlands, van den Berg et al. (2008a) show that a positive attitude of management toward the works council is associated with higher organizational performance, as perceived by management. Jirjahn and Smith (2006), too, emphasize that a positive cooperative relationship between management team and works council is important for the functioning of the works council, and so for the performance outcome for the organization. Other studies emphasize the possible negative impact of works councils. That is, works councils are often perceived as institutions that delay the decision-making process, not having enough know-how to add useful insights that facilitate effective strategic decisionmaking (van den Berg, Grift, \& van Witteloostuijn, 2008b). This is probably one of the reasons why managers try to control the decision-making process and outcome on key issues, even if they are willing to let employees participate in the decision-making process (Mizrahi, 2002).

So, we know from earlier work in the industrial relations literature that works councils operate better in some circumstances than under other conditions. The context in which works councils operate, and the support they receive from managers, is an important element in this set of contingencies (Jirjahn \& Smith, 2006). Hence, it is fair to say that the state of the art in the works council literature is associated with substantial ambiguity. Both in theory and in view of the evidence, we can find claims that the effect of works councils on organizational decision-making can be negative, neutral or positive. Therefore, further work on the underlying antecedents of the works council effect is warranted. Here, we take a route that is novel in this line of work by adopting an experimental design. We believe that this methodology is complementary to model building and field work by offering the opportunity to study fundamental processes associated with codetermination and managerial decisionmaking in a controlled setting in which variables of interest can be manipulated. Indeed, as is clear from the rapidly increasing popularity of experimental economics, this type of research design is very appropriate if one wants to explore the fundamentals of human behavior, including decision-making. It provides a useful tool to do so, because, as Butler and Hey (1987: 157) state, “[i]ts fundamental purpose is to allow competing theories to be subjected to controlled testing, to discover which ones more closely model the evidence.” Experimental research has been introduced to the field of industrial organization in the 1980s, mainly due to the influence of behavioral research (Lewin \& Feuille, 1983). A line of experimental work that is 
somewhat related to the issue of codetermination focuses on bargaining relations such as arbitration (Dickinson, 2004; Magenau, 1983) and conflict relationships between employer and employee (Bacharach \& Lawler, 1981). However, this line of research mainly deals with labor unions, and not at all with works councils. Another line of experimental work involves the impact of advice on decision-making, but these studies treat advice from similar parties, not parties with potentially conflicting interests like management teams and works councils (Schotter, 2003), or focus on advice that was paid for, not given for free such as in the case of a works council (Nyarko, Schotter, \& Sopher, 2006). So, we believe that codetermination implies a specific type of advice that features two critical characteristics: (a) the interests of the advisor and advisee are not necessarily similar, and (b) the advice is not associated with a fee. The study of types of advice that are so specific requires tailor-made experimental designs.

In the current study, we are interested in (i) whether or not managers take into account the advice they receive from their works council, (ii) whether or not works councils delay decision-making processes, and (iii) what fundamental mechanism may explain the direction of the effects. It is important to look into these questions, because it can help to gain more insights into the fundamentals that underlie the functioning of works councils in organizations, and the way their contribution is handled by managers. Of course, given that our study is the first of its kind, to the best of our knowledge, we cannot do more than offer preliminary insights into a few of the potential fundamentals. In so doing, though, we hope to offer a platform for further work adopting the experimental design tool. We are aware of the fact that a number of factors, such as the role of labor unions and the internal functioning of works councils, cannot be taken into account because we make use of a stylized experimental design. However, we believe that in order to gain more insights into the fundamental mechanisms associated with the effect of works council advice on managerial decision-making, the current experimental design can offer first answers to our research questions of interest. Before introducing our experimental protocol and the empirical findings in detail, we first set the scene by briefly introducing our setting and hypotheses. Starting point is the huge experimental literature on competitive versus cooperative behavior in the human world. 


\section{SETTING AND HYPOTHESES}

\section{Cooperative versus competitive behavior}

Cooperative and competitive behavior of humans has long been a topic of interest in economics and other social sciences, such as psychology and sociology. In the experimental tradition, so-called social dilemma games offer an ideal context for studying the drivers of competitive vis-à-vis cooperative behavior. A classic example of such a social dilemma setting is the Prisoner's Dilemma (see, for example, Boone, De Brabander, \& van Witteloostuijn, 1999). The current paper uses the Prisoner’s Dilemma setting, too, because this resembles the essence of the relation between a works council and management team. German works councils serve the interest of the workforce. Formally, Dutch works councils operate in the interest of the organization as a whole. However, in practice, issues of conflict abound in both contexts (see de Jong \& van Witteloostuijn, 2004).

We adopted the ideal-typical Prisoner’s Dilemma setting of a Bertrand duopoly with product homogeneity and nonbinding capacity constraints. The key decision involves price $(P)$. We took an adapted version of Boone et al.'s (1999) experimental setting, as this offers a stylized context to explore the effect of works council advice on managerial decision-making in a competitive marketplace. Two identical firms operate in the same market. They can choose between a high price $(H)$ and a low price $(L)$. Price is the only factor consumers base their choice of product / seller upon. Profit depends on both firms' choices - i.e., the choice of the focal as well as the rival manager, denoted as firm 1 and 2, respectively. We illustrate the nature of the game by taking the actual payoffs as used in our experiment. There, the profit combinations are as follows:

1. $P 1_{H}=P 2_{H}$. Both firms' managers choose to set a high price. This results in a profit of 90 for both firms.

2. $P 1_{L}<P 2_{H}$. The manager of firm 1 opts for a low price, while rival 2 sets a high price. The customers of firm 2 will move to firm 1, offering the lower price. Firm 1's profit is 120, while firm 2 earns nothing.

3. $P 1_{H}>P 2_{L}$. The manager of firm 1 decides to play high, making all customers run to firm 2, setting a low price. Now firm 2 will make 120, while firm 1 earns nothing.

4. $P 1_{L}=P 2_{L}$. Both firms' managers select a low price. This results in a profit of 70 for both firms. 
Both managers choose their prices simultaneously. Table 1 provides the game's payoff matrix. ${ }^{1}$

[Insert Table 1 about here]

Setting a high price would be more beneficial if the other party decides do so as well. If the other party plays low instead, the manager choosing a high price will earn nothing. Therefore, the Nash Equilibrium is where both decide to set a low price, which is the south-east corner in Table 1 . Then, neither firm is undercut by the rival. However, both firms could have been better off, would they be willing to take the risk by seeking tacit collusion by both playing high. The one-shot or finite horizon Nash equilibrium is to play low. However, if both parties play Nash, profit will be low. Alternatively, if both parties play high, profit will be high, too. Playing high is akin to cooperation. In the industrial organization (IO) literature, the outcome where both parties play high is coined tacit collusion. Playing low resembles competition. In IO, the "low price, low price" Nash equilibrium in a Bertrand duopoly is often referred to as cut-throat competition. The dilemma resides in the danger of being undercut. That is, if the focal firm plays high but the rival low, the focal firm will hit the bottom, with minimum profit, as then all customers decide to buy from the low-priced rival, leaving the focal firm with empty hands.

We introduce codetermination by adding a works council that first advises management about their preferred price decision. The above managerial tradeoff is mirrored in the works council's advice dilemma. For employees, low wages imply bad news. Low prices often lead to low wages, and thus high prices are more beneficial to the employees, ceteris paribus. This ceteris paribus clause is critical in our Bertrand duopoly context, however, because the outcome depends upon the choice made by the rival firm. After all, when the manager of the other firm chooses a low price, while the focal firm opts for a high price, wages will drop even lower (to zero, in the limit, reflecting layoffs), since there is no production. Therefore, for the employees, there will also be a trade-off between giving a high or a low price advice,

\footnotetext{
${ }^{1}$ Note that we decided not to include negative payoffs, because we know from behavioral theory that losses loom larger than gains (Kahneman \& Tversky, 1979). We preferred to avoid the trigger to play a low price instead of a high price motivated by loss aversion. However, this design decision has the implication that in the Nash equilibrium competitive outcome (both managers playing low) the firms are not that much worse off than in the tacit collusion outcome (both managers choosing high). However, we believe that the risk of not gaining anything (a payoff of zero) is large enough to create a tendency toward play the Nash equilibrium, ceteris paribus.
} 
depending upon the expectation of the other firm's price choice. With this two-layer Prisoner's Dilemma in place, we have introduced a setting that, potentially, can generate a rich set of outcomes - something we need to fully explore the fundamental works council advice - management team decision interaction.

So, for a manager who needs to make a pricing decision for the product the organization offers to the market, a dilemma occurs. If the manager goes high in an attempt to safeguard high wages in the ceteris paribus interest of employees, the firm will be outcompeted if the rival opts for the low price, so reaping the whole market. However, when the rival decides to set a high price, too, both organizations can share the market with maximum joint profit and ditto labor surplus. The Nash equilibrium is to not take the risk, but to set a low price to avoid to be outcompeted. If both firms opt for the low Nash equilibrium price, though, market-level profit and wages will be minimized. In our stylized setting, the works council is able to give an advice to the manager, so that the manager might reconsider her or his decision. To benchmark the effect of advice, we include two different settings: one in which a works council will give an advice, and one in which the firm does not operate a works council. So, managers in the current experiment can either receive advice or not. When they do receive advice, this can be to play high or low.

We play a finite game to make sure that the Nash equilibrium is the "low price, low price” outcome. In this way, in theory, the incentive to cooperate is absent. This is theory, though. Experimental evidence abounds that many players decide to play high anyway, going against the Nash equilibrium prediction (Boone et al., 1999). To the extent that players are inclined to cooperate, however, experimental evidence reveals that the incentive to do so diminishes throughout the game (Selten \& Stoecker, 1986). That is, as the game continues, actors learn about the performance effect of their strategy, in light of the responses of their counterparts. Thus, using extant game theory and evidence from experimental economics, we would expect that players will reveal a tendency to choose a low price, with an increasing tendency to play low over the course of the game. This is our benchmark prediction in the absence of advice.

\section{The nature of the decision}

Advice can have an influence on behavior in games, as Schotter (2003) has shown. He found that (a) subjects tend to follow the advice they receive and that (b) they often prefer the advice above information on which the advice was based. 
Furthermore, he concludes that subjects who received advice behaved more according to economic rationality theory than their counterparts who did not receive any advice. Schotter's interpretation is that this is probably due to the fact that subjects have to consider longer what to do after receiving advice. Accordingly, they think harder about the problem they are facing. However, we cannot extrapolate his argument to our setting so easily. Key is that the type of advice in the present study is different from Schotter's, because of our focus on the employee-employer conflict of interest (i.e., works council versus management team). Moreover, as in Schotter (2003), the advice can go either way in our setting, to opt for a low or a high price, given the ambiguity residing in the Bertrand duopoly dilemma.

The two types of advice may well have different effects on the manager. We expect that an advice to play low will increase the likelihood that the manager will decide low with even a higher tendency compared to managers receiving no advice. This expectation is based on the argument of Schotter (2003) that subjects think harder about the problem at hand after receiving an advice, and that this is associated with convergence to economic rationality - in our case, to play Nash. This we coin the rationality-increasing effect. Furthermore, following Schotter's (2003) logic, advice might impact the quality of decision-making. That is, managers are forced to take their time and think harder in the face of the legal obligation to take advice from the works council seriously, and to argue carefully why they decided what they decided. This we refer to as the scrutiny-increasing effect.

The above ignores subtleties such as moral and ethical considerations, and the context in which the decision is made, all of which are known to influence behavior in the laboratory (Levitt \& List, 2007). Having a works council in the organization adds a factor to the context of the decision - namely, a social party whose interest has to be taken into account. This is likely to trigger consideration of other-regarding preferences. In such a setting, the manager may well be inclined to take broader moral considerations on board, before making a decision, because $\mathrm{s} /$ he is aware that her or his decision has a wider impact than on the owner / shareholder's interest of profit maximization alone. Specifically, the works council will increase the saliency of the interest of the workforce, which may well be to sacrifice some profit for the sake of safeguarding a higher labor surplus. This we coin the other-regarding effect. This effect depends on the degree to which altruistic motives are salient. We believe that 
when a high advice is given, altruistic motives may well be primed. This, in turn, will lead to a higher likelihood of choosing a high price. Jointly, these effects suggest

Hypothesis 1: Managers receiving advice to play low are more likely to opt for a low price than managers not receiving advice.

Hypothesis 2: Managers receiving the advice to play high are more likely to set a high price than managers receiving the advice to choose a low price.

From a large tradition of experimentally exploring individual differences, particularly in psychology, we know that a player's background characteristics may imply a bias to behave competitively or cooperatively. By and large, these characteristics can be “objective” demographic features such as age or gender, or "subjective” characteristics such as attitudes and personalities (see Boone et al., 1999). In the current study, being the first of its kind, we decided to explore one example of either type: gender and other-regarding orientation. We included gender because this is a very salient human feature with clear behavioral consequences. We added other-regarding orientation because this lies at the heart of the social dilemma central to the management team - works council interaction, as explained above.

Firstly, the role of gender has received much attention in studies on human behavior. A priori, for a wide variety of biological and social reasons, the expectation is that women tend to behave less competitively than men do. However, the evidence is mixed (Gneezy, Niederle, \& Rustichini, 2003). For example, Stockard, van de Kragt, and Dodge (1988) found only a small difference between men and women regarding cooperative behavior. Akkermans, Harzing, and van Witteloostuijn (2009) even revealed that women behave more competitively than men in their setting, which is very similar to our Bertrand duopoly game. Because women are expected to behave differently from men, women are also expected to have a different leadership style. A meta-analysis on gender and leadership style (Eagly \& Johnson, 1990), however, failed to find consistent support for the gender stereotype that women would have a more interpersonal and men a more task-oriented style of leadership. This metaanalysis does report support for differences concerning democratic or autocratic leadership styles, though: women tend to have a more democratic and participative leadership style than men, who tend to have a more autocratic and directive style. 
Therefore, we expect that women will take the advice of works councils more seriously than their male counterparts, in the case of the advice to play low as well as the advice to play high. This implies

Hypothesis 3: Female managers are more likely to follow the advice of the works council than their male counterparts.

Secondly, the influence of other-regarding orientation is straightforward. In Beckerian terms, other-regarding or more altruistic people include the interest of others in their utility function, whilst self-regarding or more egoistic individuals do not (see, e.g., Becker, 1991). So, in our setting, we expect managers with an otherregarding orientation to be more likely to take the advice of the works council seriously than their counterparts featuring a self-regarding orientation. That is,

Hypothesis 4: Managers receiving advice are more likely to follow this advice when they are characterized by an other-regarding orientation.

\section{The speed of decision-making}

A counterproductive impact of works councils that is often mentioned in the literature is that they delay the process of decision-making (van den Berg et al., 2008a). Delay does not always have to have a negative effect on economic performance, however. For example, van den Berg et al. (2008b) find that, in private organizations, delayed decision-making is beneficial, because the works council is able to take enough time to do their work and properly to come up with a wellconsidered contribution to the decision-making process. In the current experiment, the focus is not on the performance effect of the speed of decision-making. Rather, we deal with the effect of receiving advice from a works council on the time it takes to make a decision. By way of benchmark, following Schotter (2003), we expect that managers receiving advice from a works council will need more time to reach a decision than managers not receiving advice, because they might have to (re)consider their initially intended decision. So, we have

Hypothesis 5: Managers receiving advice from a works council take more time to make a decision than managers not receiving advice. 
Furthermore, we also expect this effect to interact with gender. Because women are found to have a more democratic and participative leadership style (Eagly \& Johnson, 1990), we believe that they will take more time to consider the opinion of the other party. This gives

Hypothesis 6: Female managers receiving advice from a works council take more time to make a decision than male managers.

\section{METHOD}

\section{Sample and data-collection procedure}

We ran six experimental sessions to include four treatments: advice-advice, advice-no advice, no advice-advice, and no advice-no advice, where $x$ in this $x$ - $y$ pair refers to the manager of firm 1 and y to her or his counterpart at firm 2. Four sessions had 20 subjects, one 14 subjects, and one 16 subjects. The latter two sessions had less than 20 subjects due to no-shows. In total, 110 undergraduate students from different study programs of Utrecht University in the Netherlands participated. Sessions lasted for about three quarters of an hour, and earnings averaged $€ 8.20$ per participant. The game was played in a computer laboratory, with one computer per participant in an isolated cubicle. The experiment was programmed and conducted with the z-Tree software (Fischbacher, 2007). Subjects were randomly assigned to either the role of the works council representative or the role of the manager in charge of the price decision. Because the focus of this paper is on the influence of works council advice on managerial decision-making, as reflected in Hypotheses 1 to 6, managers were the target of the analyses reported below. Therefore, 90 subjects were assigned to the role of manager, and 20 subjects to the role of works council representative. Of these 90 managers, 50 managers received an advice from their works council, and 40 did not. In 60 per cent of the cases, works council representatives advised high. This implies that our data reflect sufficient advice content variation. ${ }^{2}$

\footnotetext{
${ }^{2}$ In the context of the current analyses, this information suffices. However, although we only have 20 participants in the role of works council representative, we plan to explore the determinants of high versus low price advice in future work, using the panel structure of our dataset. The reason why we explicitly included participants in the role of works council representatives has to with current practices in experimental economics. In terms of the ethical codes that should guide experiments, experimental economists follow much stricter guidelines than experimental psychologists, for one reason or the other. Basically, experimental economists do not tolerate any “deception”. In our context, this means
} 
The subjects played twelve periods against an opponent to whom they were randomly matched and with whom they played throughout the whole experiment. Given this and the layout of the laboratory this guarantees reciprocal anonymity. Both parties received full information regarding the rules of the game (the payoff of both parties, the fact that more than one manager was advised by one works council representative, et cetera). The works council representative decided upon an advice (a high or low price). They were told that choosing a high or a low price would have several implications. Choosing a high price is beneficial, in principle, but only when the other manager does not play a low price. If the rival firm would opt for a low price, wages will drop even lower in the focal firm than when both managers choose low. Each works council representative (20, in total) advised more managers at the same time (50, in total), but they could not advice competitors. The number of managers advised by a single works council representative ranged from two to four managers. This setup mimics a central works council (in Dutch: centrale ondernemingsraad, or COR), advising business unit managers. The payoff of the works council was not determined by the representative's advice directly, but followed from the decision made by the manager in interaction with that of the rival. The works council benefits the most if they advise high and if both managers decide to set a high price afterwards.

As explained above, a high price is not always beneficial for the manager, as a representative of the firm, because if the other manager decides to set a low price, the high-price firm will earn nothing. The payoffs for the firms are shown in Table 1 above. In the experiment, these payoffs are the firm's profits, which were translated into manager's earnings in the following way. The payoffs were represented in socalled ECU points (Experimental Currency Unit points), with an exchange rate of 100 points $=€ 1$. The subjects played a two-player iterative Prisoner's Dilemma game (PD game), where they had to decide upon a price. They thus played a Bertrand duopoly game. After the works council representative had given an advice (low price or high price), if any, the managers in the "advice” group received their advice. Subsequently, all managers had to decide upon a price. The profits of every decision round were shown after the price decisions had been revealed: in terms of "Your choice”, "The 
other manager's choice” and "Your profit” in that round. The experiment setup is represented in Figure 1.

[Insert Figure 1 about here]

\section{Measures}

The dependent variable that is used to test the first four hypotheses is Decision content, being the decision the managers made: choosing a low (0) or a high price (1). Table 2 shows the descriptive statistics of and correlations among the variables. Here we can see that the majority of subjects played competitively: 82 per cent of the participants' decisions were to play low, cumulated over the twelve rounds. This can also be observed in Figure 2, which shows the mean decisions of the managers over the twelve periods. Here, the end period effect can be observed as well, as is common in the case of finite horizon games: the mean number of high prices decreases over time. In the first and last round, managers receiving the advice to play high have the highest tendency to choose a high price, and the managers receiving the advice to play low reveal a higher tendency to select a low price. This pattern is less clear in round 2 to 11. Remarkably, managers receiving no advice reveal a higher tendency to play high than the managers who received the advice to set a high price. The second dependent variable, Decision time, is used to test Hypotheses 5 and 6. Decision time was measured as the time the subjects took before typing in their decision. The participants took, on average, 3.6 seconds to make a decision. Figure 3 shows the average decision time over the twelve rounds. Visual inspection does not reveal a clear pattern across the three different conditions.

[Insert Figures 2 and 3 about here]

Our first independent variable is the type of Advice received, varying from №

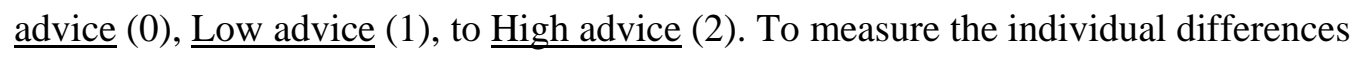
regarding self versus other-regarding orientation, we used the psychological social value orientation typology (van Lange, Otten, de Bruin, \& Joireman, 1997). This typology classifies subjects in three categories: prosocial, individualistic, and competitive. The first group tends to maximize outcomes for themselves as well as others, striving for equality; the second group seeks to maximize own outcomes, not taking into account others' outcomes; and the last group aims for relative advantage over others. The social value orientation questionnaire consists of nine questions, in which three forced-choice options are given, reflecting the three types of orientation. 
We decided against the use of the three discrete categories as our measure, but rather opted to create a continuous variable referred to as Orientation, with higher scores reflecting a more other-regarding orientation. The mean score is 3.17 , with a range from 0 to 9 .

To test our fourth hypothesis, we generated a product term variable of

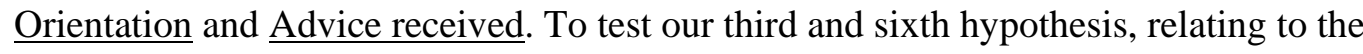
interactions of type of advice with Gender ( 1 for females and 0 for males), we generated a product term of Gender and Advice received. Women were overrepresented in our sample, with 68 per cent of the participants being female. This might be due to female-biased self-selection into experiments (Levitt \& List, 2007). Tables 2 to 4 show the descriptive statistics and Spearman correlations, for the whole group (Table 2), and for the advice group and no advice group separately (Tables 3 and 4).

[Insert Tables 2 to 4 about here]

We controlled for the Age (mean age is 21) and Nationality of the subjects. Age is known to be positively associated with cooperative behavior. We created a dummy variable for having a Dutch $(76 \%)$ or a non-Dutch nationality $(24 \%)$. We chose to control for this, because the way Dutch works councils are functioning is characteristic for the Dutch "poldermodel”, reflecting a cooperative industrial relations practice. Subjects with non-Dutch nationalities may perceive a works council as less important than Dutch participants. Furthermore, we added a dummy variable to control for the type of Study program. Given extant evidence, economics students are expected to behave more competitively than their non-economics counterparts, because they are familiar with the concept of the Nash equilibrium, and are taught to believe in the dominant conception of economic agents guided by the self-interest model of utility maximization, which is particularly dominant in IO economics through the assumption of firm profit maximization (see, e.g., Jansen, van Lier, \& van Witteloostuijn, 2007). Of the sample, 23 per cent were economics students.

Because the subjects played against the same participants over all twelve rounds, we must control for the decision made by the opponent in the previous round. Tit-for-tat logic implies that if the opponent played a low price in the previous round, the focal participant is likely to retaliate by playing low, too, in the next round. For a high price, the prediction is unclear. If the opponent played a high price in the 
previous round, the focal subject might want to play a high price as well, to both benefit from the higher payoff associated with tacit collusion. Alternatively, though, the focal participant might decide to defect from cooperation, leaving the opponent with nothing and reaping the top payoff her or himself. To control for this effect, we included the Other's decision (lagged). Moreover, because we played a repeated game, learning effects are likely to occur. For instance, subjects may learn that choosing a high price is not always beneficial. We expect that over time cooperation will go down, as a result, because of the end horizon effect that occurs in a finite Prisoner's Dilemma game (Selten \& Stoecker, 1986). This is controlled for by including the Number of the period in the analyses.

Finally, for the analysis regarding decision time, we included whether the advice was followed or not, referred to as Match, as a control variable. Subjects might take less time when their initially intended decision matches the advice they received. In our context, when the works council advises to choose the price level that the manager would initially also have chosen her or himself, in the absence of advice, then the time taken to make this decision might well be less.

\section{Methods}

We performed analyses including all periods, interpreting the dataset as a panel. $^{3}$ To explain the decision of the managers over time, we used a generalized estimating equation model (GEE) (Liang \& Zeger, 1986; Zorn, 2001). This approach is used to estimate population-averaged effects, while random effects models can be applied to estimate subject-specific effects. Because we want to make inferences about the different treatments (types of advice) over time, we chose the GEE approach. The GEE method takes into account the dependence between the measurements by means of a working correlation matrix. The most common types of working correlation matrices are independent, exchangeable, auto-regressive (AR1), and unstructured matrices (Lee, Herzog, Meade, Webb, \& Brandon, 2007). Choosing a good working correlation matrix will benefit the accuracy of our estimates. Note, however, that the parameter estimates of interest will also be consistent if the

\footnotetext{
${ }^{3}$ We also performed an analysis with the first eleven periods, leaving out round 12, to control for the end horizon effect, but the results were similar to the analyses with twelve periods reported in the paper.
} 
correlation structure is incorrect (Zorn, 2001). The correlation structure can be decided upon based on several grounds. First, substantive reasons related to the structure of the data provide the most important arguments to choose one structure over the other. Furthermore, the QIC test (quasi-likelihood under the independence model criterion) can help to determine which correlation structure fits the data best. The lower the QIC, the better fit the correlation structure reveals (Hin, Carey, \& Wang, 2007; Pan, 2001). The QIC for the current analyses indicated that the AR1 (auto-regressive) structure is to be preferred (available upon request). This is in line with substantive arguments, because our data have a longitudinal character.

We performed several analyses to test our hypotheses. First, we tested for the effect of type of advice on the whole group. After testing for that effect, we split the data into two groups: the group that received the advice to play a low price versus the group that received the advice to play a high price. In this way, we were able to obtain different sets of estimates that may reveal differences across both groups. We did this for both analyses, for decision content and for decision time. We performed all analyses in Stata 10 (StataCorp, 2007).

\section{RESULTS}

Table 5 shows the results of our analysis for Decision content. We are interested in whether advice has an impact on the decisions that managers make. We expect low advice to lead to a low price and high advice to lead to a high price, respectively (Hypotheses 1 and 2). The type of advice is jointly significant in Model 1 $\left(\chi_{2}^{2}=9.38, p=0.01\right)$. Subjects who receive advice to set a low price have a significantly higher tendency to choose a low price than subjects who do not receive any advice. Furthermore, Model 4 supports the importance of the advice received: subjects who receive a high advice, have a higher likelihood of setting a high price than subjects who receive advice to choose a low price. These findings yield support for our first two hypotheses.

\section{[Insert Table 5 about here]}

The interaction effects are shown in Model 2. Both hypothesized interactions of advice received with gender and other-regarding orientation are significant (with gender: $\chi_{2}^{2}=4.75, p=0.09$; with other-regarding orientation: $\chi_{2}^{2}=9.68, p=0.01$ ) Females receiving an advice to choose a low price have a higher tendency to do so. 
Similarly, when they receive a high price advice, they have a higher tendency to set a high price. This finding offers support for Hypothesis 3. The gender interaction effect is visualized in Figure 4. Remarkably, male subjects receiving no advice at all have the highest tendency to choose a high price.

Furthermore, subjects with an other-regarding orientation receiving a low advice have a higher tendency to decide for a high price than their other-regarding orientation counterparts receiving no advice. This can be seen in Figure 5. For participants receiving no advice, we observe that their choice is not affected by their other or self-regarding orientation. When subjects receive a high advice, the likelihood to set a high price increases with other-regarding orientation. This effect is even larger for subjects who receive the advice to decide for a low price. This latter finding goes against our expectation. This gives only partial support for Hypothesis 4 . In principle, after all, we would expect an other-regarding orientation to trigger the decision to follow the works council's advice, whether high or low. An interpretation for the non-expected result may be that other-regarding subjects feel inclined to correct the low advice of the works council because they believe that setting a high price is more likely to be beneficial for the works council. Thus, having a high otherregarding orientation leads to a higher tendency to set a high price irrespective of the advice received.

\section{[Insert Figures 4 and 5 about here]}

The control variables relating to the characteristics of the subject (age, nationality, study and gender) are insignificant. The significant coefficient of otherregarding orientation indicates that the higher the other-regarding orientation, the higher the likelihood of setting a high price. This is in line with the interaction effect of the advice received with orientation. The lagged other manager's decision is significant, as expected: if the other manager played high in the previous round, the likelihood to set a high price in the current round increases. The number of period is significant, too, revealing a diminishing tendency to cooperate over time.

Table 6 reports the results for decision time. Model 1 reveals that the effect of whether or not receiving advice is insignificant. So, Hypothesis 5 is not supported. However, the interaction effect of advice received with gender is jointly significant $\left(\chi_{2}^{2}=11.15, p=0.00\right)$. Figure 6 visualizes this interaction effect. Female subjects take more time than their male counterparts to decide after receiving advice, as 
predicted. Hence, Hypothesis 6 is supported. Furthermore, male participants who do not receive advice are the slowest decision-makers.

[Insert Figure 6 and Table 6 about here]

Nationality has a significant effect, indicating that Dutch subjects are slightly faster in making their decision than subjects with other nationalities. Comparing across groups (Models 3 to 5), we see that gender has a significantly negative effect in the no advice group and a significantly positive effect in the advice group. This indicates that females need less time than males when they receive no advice, and vice vers $a$ when they receive advice. This is in line with the interaction effect. Further, in the advice group (Models 4 and 5), the lagged decision of the opponent does matter. Probably, the combination of both pieces of information, the opponent's lagged decision and the works council's advice, gives extra food for thought. All models show that subjects need less time to make a decision over time (number of period). Whether the decision made matches the advice received does not affect the time needed to make a decision.

\section{DISCUSSION}

In our stylized experimental setting, advice given by the works council representative has an effect on the decision managers make. On the one hand, as expected, managers receiving a low price reveal a higher tendency to indeed set a low price. This confirms the finding of Schotter (2003), who found that receiving advice leads to more economically rational behavior. Playing low is the rational Nash equilibrium choice in our Bertrand duopoly context. The fact that the works council's advice is in line with the rational Nash equilibrium choice makes the tendency to opt for a low price even higher. On the other hand, however, when moral considerations come into play, meaning that the works council advices the manager to behave cooperatively by playing high, we also see that managers tend to follow this advice. In so doing, their behavior goes against the prediction of the rational Nash equilibrium. To unravel the mechanism underlying these contrasting effects, we explored a number of interaction effects, focusing on two individual characteristics of our managers: gender and other-regarding orientation.

First, indeed, female managers tend to follow the advice of the works council more often than their male counterparts. Interestingly, male managers who do not 
receive any advice have the highest tendency to set a high price. Other mechanisms might be at work here, since the role of advice is not important in this case. Further interaction effects with, for example, other-regarding orientation or the other's decision (lagged) might play a role. Future research is needed to further explore gender effects in strategic decisions in the context of codetermination. An option is to replicate our experiment with a larger and more varied sample of subjects. Also, we plan to move beyond the current Bertrand duopoly setting by designing more complicated experimental protocols.

Second, managers with an other-regarding orientation reveal more cooperative behavior than managers with a self-regarding orientation. This especially holds for managers who are advised to choose a low price. In this case, other-regarding oriented managers even decide to not follow the advice of the works council to play low, but rather opt for a high price. They probably do so because they believe that a high price is more likely to be in the works council's interest. The pro-social behavior of the other-regarding oriented managers might thus be beneficial for the other manager as well as for the works council. Again, future research is needed to deepen our understanding of the role of managerial personality traits in the context of codetermination.

Regarding the delay of decision-making, unexpectedly, whether or not managers receive advice does not have any effect. So, our managers do not need more time to decide on their price after receiving advice from a works council. Here, too, future research is needed. It would be interesting, for instance, to take a closer look at the effect of the initial decision intention of the managers. In that case, a different experimental setup is needed, in which managers make their decision before receiving advice, receiving advice afterwards with the possibility to change their decision. In the context of our experiment, however, we explored underlying mechanisms in more detail by estimating the interaction effect involving gender.

Indeed, female managers receiving an advice do tend to take longer to make their decision. An explanation might be that females are more often associated with a democratic and participative leadership style (Eagly \& Johnson, 1990). Hence, they have to rethink their initial decision intention to take into account the works council advice. In future work, a measure of the managers' leadership style could be included. Morerover, as with the gender effect in the nature of the decision analyses, male managers who did not receive any advice take the most time to make a decision. As 
suggested above, this might be due to other processes unobserved in our design, implying a need to explore this unexpected gender effect further in future research.

A limitation of this study is, of course, that we cannot be sure about the generalizability of our findings. An advantage of the experimental design is high internal validity. However, further research should explore the robustness of our findings in other experimental settings, as well as in field work. Above, we referred to a few alternative experimental protocols we would like to explore in future work. Moreover, regarding external validity, as Levitt and List (2007: 170) argue, " $[\mathrm{k}]$ nowing the sign and plausible magnitude of any biases induced by the lab, one can extract useful information from a study, even if the results cannot be seamlessly extrapolated outside the lab”. Clearly, our experimental study is only a first step to reveal some of the fundamental mechanisms involving works council advice. We hope this study will prove to offer a inspiring steppingstone to explore further in what way works councils can act optimally in influencing managerial decision-making, and thereby improving organizational functioning, by making use of experimental designs, next to and on top of field work. 


\section{REFERENCES}

Addison, J. T., Schnabel, C., \& Wagner, J. (2001). Works councils in Germany: Their effects on establishment performance. Oxford Economic Papers, 53, 659-694.

Akkermans, D. H. M., Harzing, A., \& Van Witteloostuijn, A. (2009). Cultural accommodation and language priming: Competitive versus cooperative behavior in a Prisoner's Dilemma game, International Management Review (forthcoming).

Bacharach, S. B., \& Lawler, E. J. (1981). Power and tactics in bargaining. Industrial and Labor Relations Review, 34(2), 219-233.

Becker, G.S. (1991). A treatise on the family (Enlarged ed.). Cambridge, Massachusetts: Harvard University Press.

Boone, C., De Brabander, B., \& Van Witteloostuijn, A. (1999). The impact of personality on behavior in five Prisoner's Dilemma games. Journal of Economic Psychology, 20(3), 343-377.

Butler, D. J., \& Hey, J. D. (1987). Experimental economics: An introduction. Empirica, 14(2), 157-186.

De Jong, G., \& Van Witteloostuijn, A. (2004). Successful corporate democracy: Sustainable cooperation of capital and labor in the Dutch Breman Group. Academy of Management Executive, 18(3), 54-66.

Dickinson, D. L. (2004). A comparison of conventional, final-offer, and "combined" arbitration for dispute resolution. Industrial and Labor Relations Review, 57(2), 288-301.

Eagly, A. H., \& Johnson, B. T. (1990). Gender and leadership style: A meta-analysis. Psychological Bulletin, 108(2), 233-256.

Fischbacher, U. (2007). z-Tree: Zurich toolbox for ready-made economic experiments. Experimental Economics, 10(2), 171-178.

Gneezy, U., Niederle, M., \& Rustichini, A. (2003). Performance in competitive environments: gender differences. Quarterly Journal of Economics, 118(3), 1049-1074.

Hin, L.-Y., Carey, V. J., \& Wang, Y.-G. (2007). Criteria for working-correlationstructure selection in GEE. The American Statistician, 61(4), 360-364.

Jansen, T., Van Lier, A., \& Van Witteloostuijn, A. (2007). A note on strategic delegation: The market share case. International Journal of Industrial Organization, 25(3), 531-539.

Jirjahn, U., \& Smith, S. C. (2006). What factors lead management to support or oppose employee participation - with and without works councils? Hypotheses and evidence from Germany. Industrial Relations: A Journal of Economy and Society, 45(4), 650-680.

Kahneman, D., \& Tversky, A. (1979). Prospect theory: An analysis of decision under risk. Econometrica, 47(2), 263-291.

Lee, J.-H., Herzog, T. A., Meade, C. D., Webb, M. S., \& Brandon, T. H. (2007). The use of GEE for analyzing longitudinal binomial data: A primer using data from a tobacco intervention. Addictive Behaviors, 32(1), 187-193.

Levitt, S. D., \& List, J. A. (2007). What do laboratory experiments measuring social preferences reveal about the real world? The Journal of Economic Perspectives, 21(2), 153-174.

Lewin, D., \& Feuille, P. (1983). Behavioral research in industrial relations. Industrial and Labor Relations Review, 36(3), 341-360. 
Liang, K.-Y., \& Zeger, S. L. (1986). Longitudinal data analysis using generalized linear models. Biometrika, 73(1), 13-22.

Magenau, J. M. (1983). The impact of alternative impasse procedures on bargaining: A laboratory experiment. Industrial and Labor Relations Review, 36(3), 361377.

Mizrahi, S. (2002). Workers' participation in decision-making processes and firm stability. British Journal of Industrial Relations, 40(4), 689-707.

Nyarko, Y., Schotter, A., \& Sopher, B. (2006). On the informational content of advice: a theoretical and experimental study. Economic Theory, 29(2), 433452.

Pan, W. (2001). Akaike's information criterion in generalized estimating equations. Biometrics, 57(1), 120-125.

Schotter, A. (2003). Decision making with naive advice. The American Economic Review, 93(2), 196-201.

Selten, R., \& Stoecker, R. (1986). End behavior in sequences of finite Prisoner's Dilemma supergames A learning theory approach. Journal of Economic Behavior \& Organization, 7(1), 47-70.

StataCorp. (2007). Stata Statistical Software: Release 10. College Station, TX: StataCorp LP.

Stockard, J., Van de Kragt, A. J. C., \& Dodge, P. J. (1988). Gender roles and behavior in social dilemmas: Are there sex differences in cooperation and in its justification? Social Psychology Quarterly, 51(2), 154-163.

Van den Berg, A., Grift, Y., \& Van Witteloostuijn, A. (2008a). Managerial perceptions of works councils' effectiveness in the Netherlands: Utrecht School of Economics, Tjalling C. Koopmans Research Institute.

Van den Berg, A., Grift, Y., \& Van Witteloostuijn, A. (2008b). Works councils and organizational performance. The role of top managers' and works councils' attitudes in bad vis-à-vis good times: Utrecht School of Economics: Tjalling C. Koopmans Research Institute.

Van Lange, P. A. M., Otten, W., De Bruin, E. M. N., \& Joireman, J. A. (1997). Development of prosocial, individualistic, and competitive orientations: Theory and preliminary evidence. Journal of Personality and Social Psychology, 73(4), 733-746.

Wever, K. S. (1994). Learning from works councils: Five unspectacular cases from Germany. Industrial Relations, 33(4), 467-481.

Zorn, C. J. W. (2001). Generalized estimating equation models for correlated data: A review with applications. American Journal of Political Science, 45(2), 470490. 
Table 1. Payoff matrix

\begin{tabular}{|c|c|c|}
\hline \multirow{2}{*}{$\begin{array}{c}\text { FIRM 1's CHOICE } \\
\text { High price }\end{array}$} & High price & Low price \\
\hline \multirow{2}{*}{ Low price } & $(90,90)$ & $(0,120)$ \\
\cline { 2 - 3 } & $(120,0)$ & $(70,70)$ \\
\hline
\end{tabular}



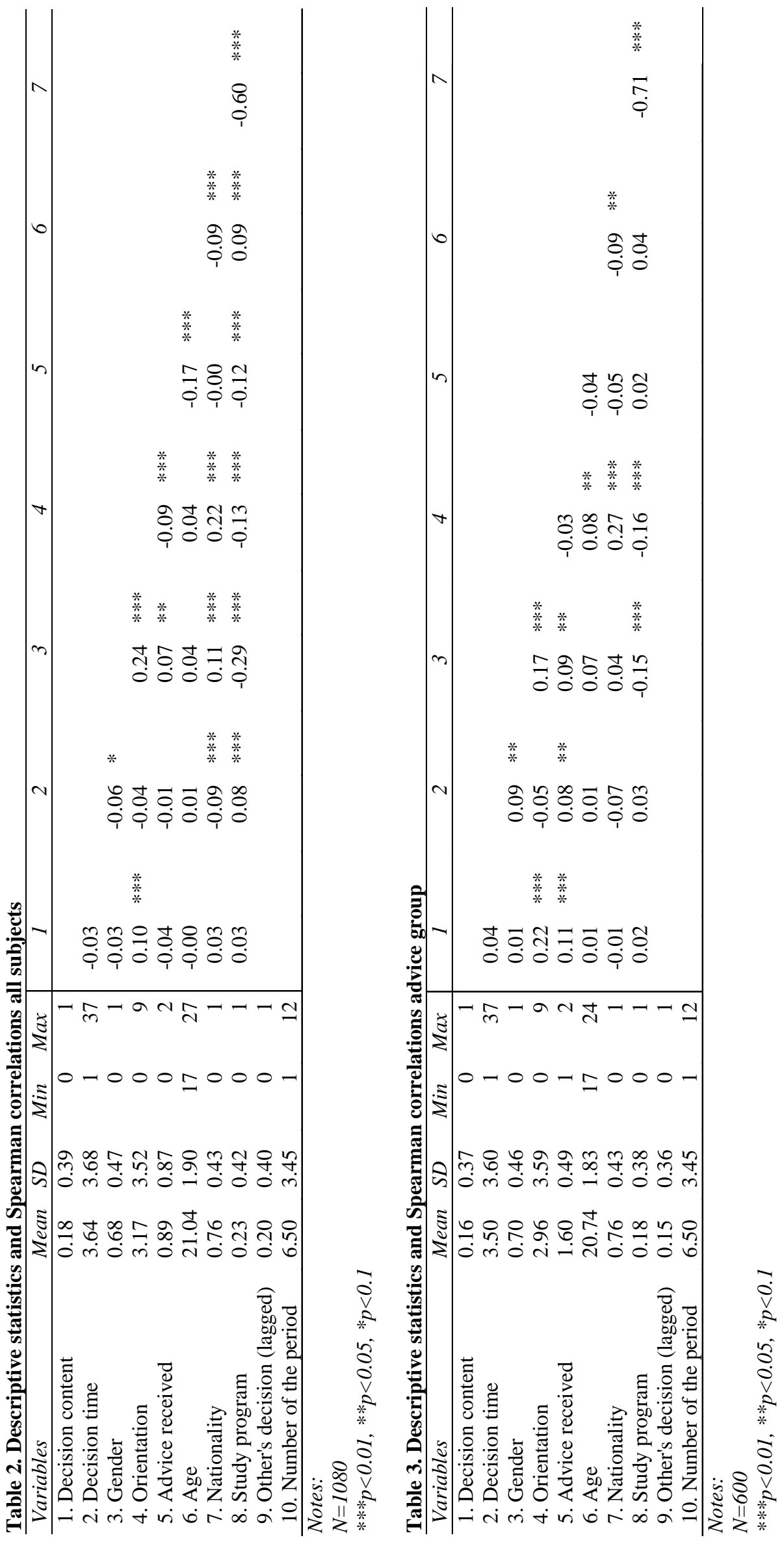


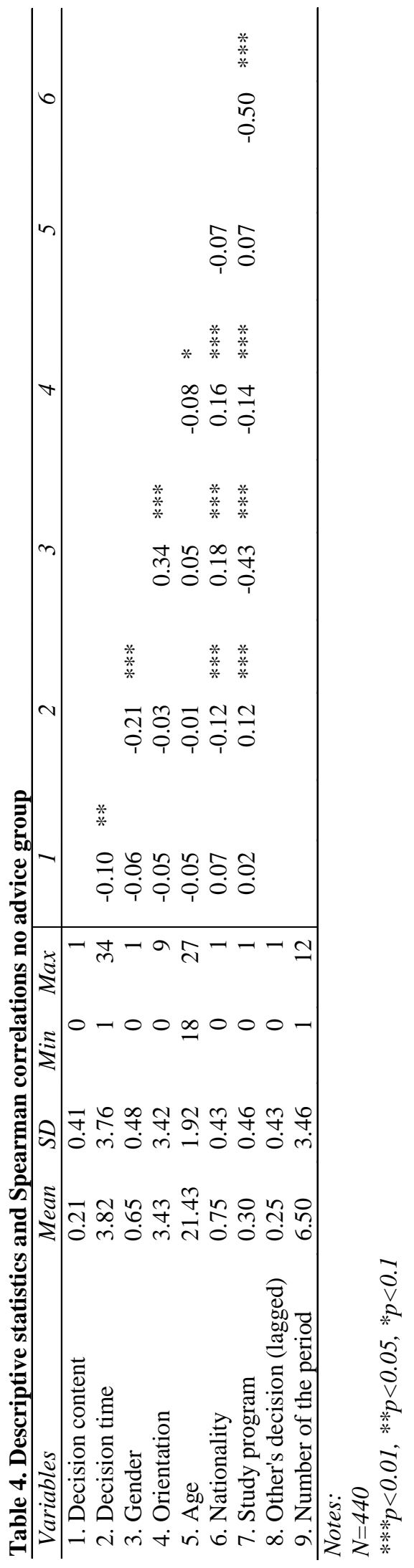


Table 5. Explaining decision content

\begin{tabular}{|c|c|c|c|c|c|}
\hline Variables & Model 1 & Model 2 & Model 3 & Model 4 & Model 5 \\
\hline Age & $\begin{array}{c}-0.074 \\
(0.072)\end{array}$ & $\begin{array}{l}-0.067 \\
(0.070)\end{array}$ & $\begin{array}{l}-0.111 \\
(0.116)\end{array}$ & $\begin{array}{l}-0.031 \\
(0.092)\end{array}$ & $\begin{array}{l}-0.002 \\
(0.092)\end{array}$ \\
\hline Nationality & $\begin{array}{c}0.136 \\
(0.390)\end{array}$ & $\begin{array}{c}0.110 \\
(0.385)\end{array}$ & $\begin{array}{c}0.590 \\
(0.601)\end{array}$ & $\begin{array}{l}-0.638 \\
(0.630)\end{array}$ & $\begin{array}{l}-0.535 \\
(0.625)\end{array}$ \\
\hline Study program & $\begin{array}{c}0.209 \\
(0.392)\end{array}$ & $\begin{array}{c}0.205 \\
(0.394)\end{array}$ & $\begin{array}{c}0.192 \\
(0.566)\end{array}$ & $\begin{array}{c}-0.113 \\
(0.667)\end{array}$ & $\begin{array}{l}-0.028 \\
(0.664)\end{array}$ \\
\hline Other’s decision (lagged) & $\begin{array}{c}1.362 * * * \\
(0.209)\end{array}$ & $\begin{array}{c}1.360 * * * \\
(0.212)\end{array}$ & $\begin{array}{c}0.899 * * * \\
(0.273)\end{array}$ & $\begin{array}{c}1.400 * * * \\
(0.314)\end{array}$ & $\begin{array}{c}1.333 * * * \\
(0.316)\end{array}$ \\
\hline Number of the period & $\begin{array}{c}-0.149 * * * \\
(0.040)\end{array}$ & $\begin{array}{c}-0.168 * * * \\
(0.040)\end{array}$ & $\begin{array}{c}-0.170 * * * \\
(0.061)\end{array}$ & $\begin{array}{c}-0.167 * * * \\
(0.055)\end{array}$ & $\begin{array}{c}-0.191 * * * \\
(0.056)\end{array}$ \\
\hline Gender & $\begin{array}{c}-0.257 \\
(0.290)\end{array}$ & $\begin{array}{c}-0.205 \\
(0.406)\end{array}$ & $\begin{array}{l}-0.258 \\
(0.498)\end{array}$ & $\begin{array}{c}-0.146 \\
(0.377)\end{array}$ & $\begin{array}{c}-0.916 \\
(0.595)\end{array}$ \\
\hline Orientation & $\begin{array}{c}0.090 * * \\
(0.037)\end{array}$ & $\begin{array}{c}-0.011 \\
(0.055)\end{array}$ & $\begin{array}{l}-0.029 \\
(0.066)\end{array}$ & $\begin{array}{c}0.201^{* * *} \\
(0.048)\end{array}$ & $\begin{array}{c}0.329 * * * \\
(0.087)\end{array}$ \\
\hline Advice received low & $\begin{array}{c}-0.841^{* *} \\
(0.345)\end{array}$ & $\begin{array}{c}-1.718^{* *} \\
(0.742)\end{array}$ & & & \\
\hline Advice received high & $\begin{array}{c}0.008 \\
(0.270)\end{array}$ & $\begin{array}{c}-0.923 * \\
(0.529)\end{array}$ & & $\begin{array}{c}0.850 * * * \\
(0.306)\end{array}$ & $\begin{array}{c}0.823 \\
(0.747)\end{array}$ \\
\hline Gender*Advice received low & & $\begin{array}{l}-0.751 \\
(0.721)\end{array}$ & & & \\
\hline Gender*Advice received high & & $\begin{array}{c}0.661 \\
(0.606)\end{array}$ & & & $\begin{array}{c}1.379 * * \\
(0.688)\end{array}$ \\
\hline Orientation*Advice received low & & $\begin{array}{c}0.320 * * * \\
(0.103)\end{array}$ & & & \\
\hline Orientation*Advice received high & & $\begin{array}{c}0.114 \\
(0.076)\end{array}$ & & & $\begin{array}{c}-0.199 * * \\
(0.093)\end{array}$ \\
\hline Constant & $\begin{array}{c}0.270 \\
(1.592)\end{array}$ & $\begin{array}{c}0.582 \\
(1.584) \\
\end{array}$ & $\begin{array}{c}1.406 \\
(2.555) \\
\end{array}$ & $\begin{array}{c}-1.221 \\
(2.042) \\
\end{array}$ & $\begin{array}{c}-1.955 \\
(2.197) \\
\end{array}$ \\
\hline Observations & 990 & 990 & 440 & 550 & 550 \\
\hline Number of subjects & 90 & 90 & 40 & 50 & 50 \\
\hline Model chi-squared & $75.91 * * *$ & $83.16 * * *$ & $22.13^{* * *}$ & $53.91 * * *$ & $53.90 * * *$ \\
\hline
\end{tabular}


Table 6. Explaining decision time

\begin{tabular}{|c|c|c|c|c|c|}
\hline Variables & Model 1 & Model 2 & Model 3 & Model 4 & Model 5 \\
\hline$\overline{\text { Age }}$ & $\begin{array}{l}-0.045 \\
(0.071)\end{array}$ & $\begin{array}{l}-0.047 \\
(0.071)\end{array}$ & $\begin{array}{c}0.016 \\
(0.121)\end{array}$ & $\begin{array}{l}-0.100 \\
(0.083)\end{array}$ & $\begin{array}{l}-0.096 \\
(0.083)\end{array}$ \\
\hline Nationality & $\begin{array}{c}-0.699 * \\
(0.396)\end{array}$ & $\begin{array}{c}-0.789 * * \\
(0.392)\end{array}$ & $\begin{array}{c}-0.616 \\
(0.621)\end{array}$ & $\begin{array}{c}-0.940^{*} \\
(0.512)\end{array}$ & $\begin{array}{c}-0.959 * \\
(0.517)\end{array}$ \\
\hline Study program & $\begin{array}{c}0.050 \\
(0.416)\end{array}$ & $\begin{array}{c}-0.188 \\
(0.416)\end{array}$ & $\begin{array}{l}-0.118 \\
(0.638)\end{array}$ & $\begin{array}{c}-0.345 \\
(0.561)\end{array}$ & $\begin{array}{l}-0.368 \\
(0.563)\end{array}$ \\
\hline Other’s decision (lagged) & $\begin{array}{c}0.127 \\
(0.284)\end{array}$ & $\begin{array}{c}0.112 \\
(0.284)\end{array}$ & $\begin{array}{l}-0.577 \\
(0.397)\end{array}$ & $\begin{array}{c}0.897 * * \\
(0.397)\end{array}$ & $\begin{array}{c}0.909 * * \\
(0.397)\end{array}$ \\
\hline Match & $\begin{array}{c}-0.041 \\
(0.383)\end{array}$ & $\begin{array}{c}-0.082 \\
(0.390)\end{array}$ & & $\begin{array}{c}-0.183 \\
(0.386)\end{array}$ & $\begin{array}{c}-0.165 \\
(0.395)\end{array}$ \\
\hline Number of the period & $\begin{array}{c}-0.179 * * * \\
(0.040)\end{array}$ & $\begin{array}{c}-0.177 * * * \\
(0.040)\end{array}$ & $\begin{array}{c}-0.142^{* *} \\
(0.066)\end{array}$ & $\begin{array}{c}-0.192 * * * \\
(0.048)\end{array}$ & $\begin{array}{c}-0.187 * * * \\
(0.048)\end{array}$ \\
\hline Gender & $\begin{array}{l}-0.227 \\
(0.305)\end{array}$ & $\begin{array}{c}-1.310^{* * * *} \\
(0.455)\end{array}$ & $\begin{array}{c}-1.416^{* *} \\
(0.560)\end{array}$ & $\begin{array}{l}0.642^{*} \\
(0.335)\end{array}$ & $\begin{array}{l}0.836^{*} \\
(0.462)\end{array}$ \\
\hline Orientation & $\begin{array}{c}0.011 \\
(0.039)\end{array}$ & $\begin{array}{c}0.012 \\
(0.061)\end{array}$ & $\begin{array}{c}0.010 \\
(0.072)\end{array}$ & $\begin{array}{c}0.019 \\
(0.044)\end{array}$ & $\begin{array}{c}0.029 \\
(0.062)\end{array}$ \\
\hline Advice received low & $\begin{array}{l}-0.278 \\
(0.472)\end{array}$ & $\begin{array}{c}-1.757 * * \\
(0.698)\end{array}$ & & & \\
\hline Advice received high & $\begin{array}{l}-0.217 \\
(0.307)\end{array}$ & $\begin{array}{c}-1.425 * * \\
(0.562)\end{array}$ & & $\begin{array}{l}-0.054 \\
(0.395)\end{array}$ & $\begin{array}{c}0.247 \\
(0.636)\end{array}$ \\
\hline Gender*Advice received low & & $\begin{array}{c}2.159 * * * \\
(0.671)\end{array}$ & & & \\
\hline Gender*Advice received high & & $\begin{array}{c}1.697 * * * \\
(0.653)\end{array}$ & & & $\begin{array}{l}-0.359 \\
(0.606)\end{array}$ \\
\hline Orientation*Advice received low & & $\begin{array}{c}0.019 \\
(0.090)\end{array}$ & & & \\
\hline Orientation*Advice received high & & $\begin{array}{c}0.017 \\
(0.086)\end{array}$ & & & $\begin{array}{c}-0.012 \\
(0.080)\end{array}$ \\
\hline Constant & $\begin{array}{c}6.452 * * * \\
(1.614) \\
\end{array}$ & $\begin{array}{c}7.316^{* * *} \\
(1.632) \\
\end{array}$ & $\begin{array}{c}5.847 * * \\
(2.694) \\
\end{array}$ & $\begin{array}{c}6.867 * * * \\
(1.853) \\
\end{array}$ & $\begin{array}{c}6.574 * * * \\
(1.916) \\
\end{array}$ \\
\hline Obse & 990 & 990 & 440 & 550 & 550 \\
\hline Number of sul & 90 & 90 & 40 & 50 & 50 \\
\hline Model chi-squared & $30.06 * * *$ & $42.94 * * *$ & $15.64 * *$ & $37.55^{* * *}$ & $37.99 * * *$ \\
\hline
\end{tabular}

Notes: Standard errors in parentheses; ${ }^{* * *} p<0.01,{ }^{* *} p<0.05$, and ${ }^{*} p<0.1$. 
Experimental group:

Managers receiving advice

Game:

12 rounds, matched to manager receiving advice or not receiving advice

$N$ (opponent advice $)=26$

$N$ (opponent no advice $)=24$

$N$ total $=50$
Control group:

Managers not receiving advice

Game:

12 rounds, matched to manager receiving advice or not receiving advice

$N$ (opponent advice $)=24$

$N$ (opponent no advice $)=16$

$N$ total $=40$

Figure 1. Experimental setup 


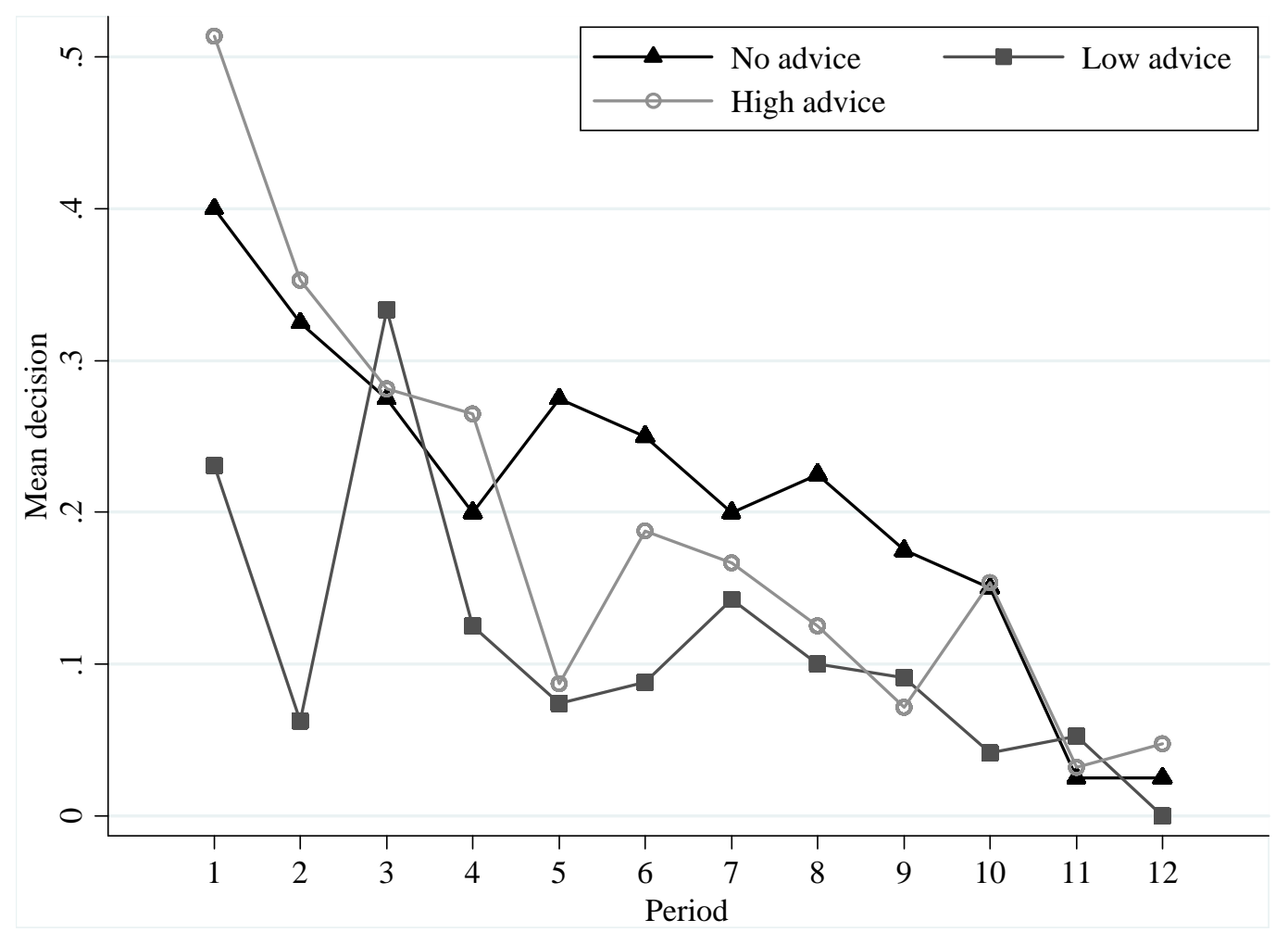

Figure 2. Mean decision content over twelve periods 


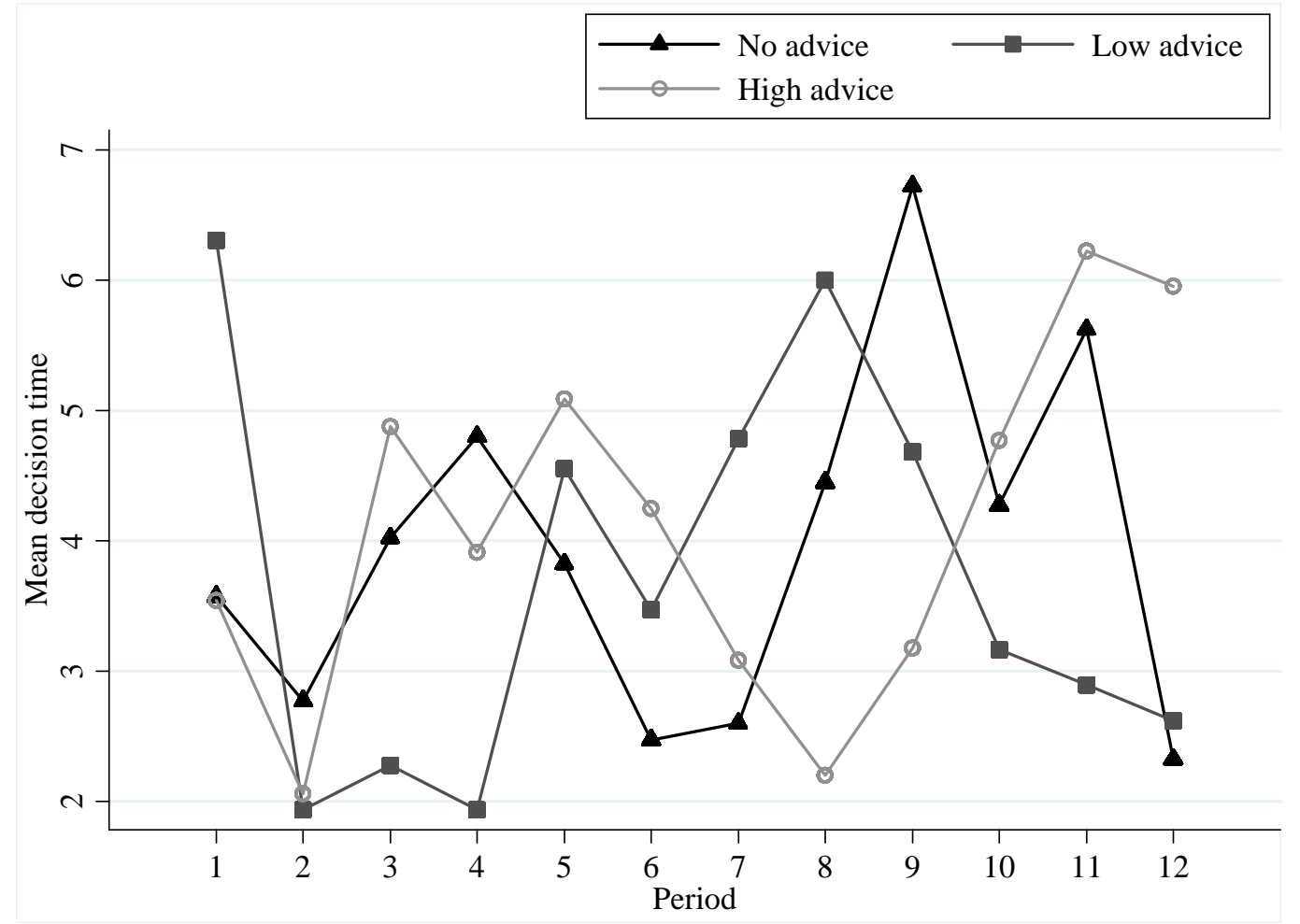

Figure 3. Mean decision time over twelve periods 


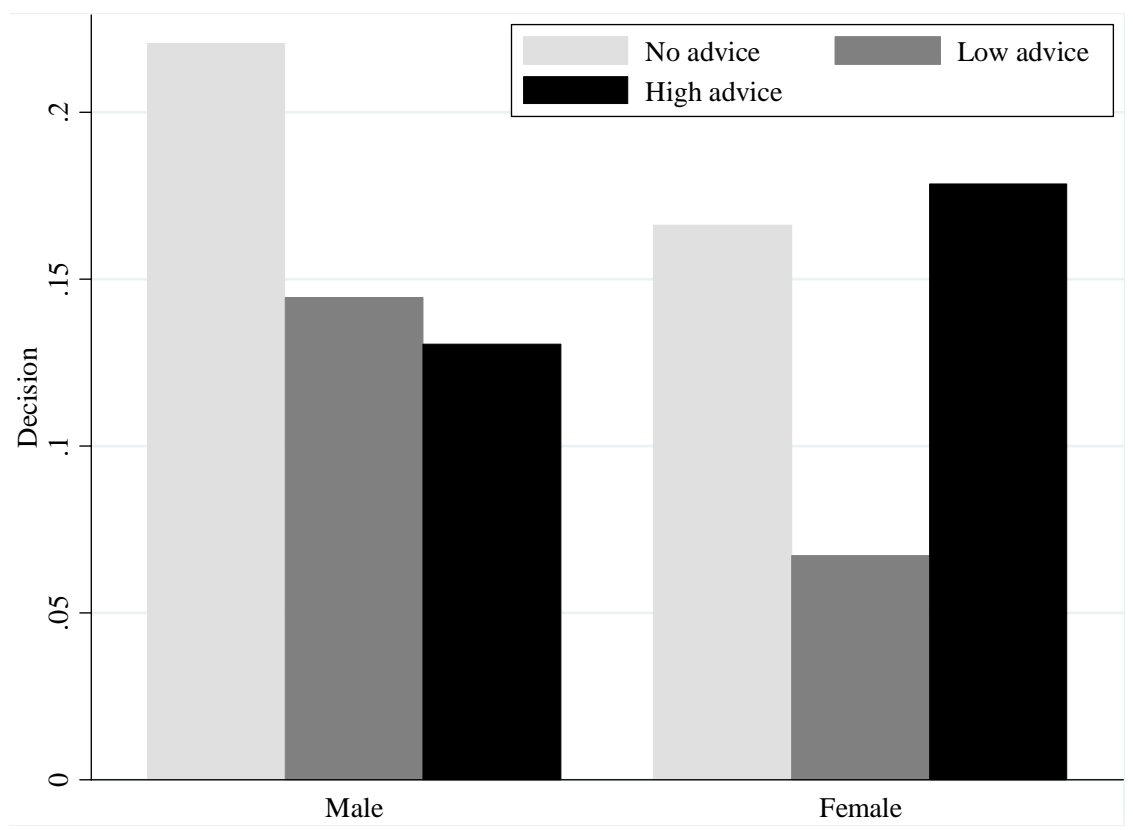

Figure 4. Interaction effect of gender and advice received 


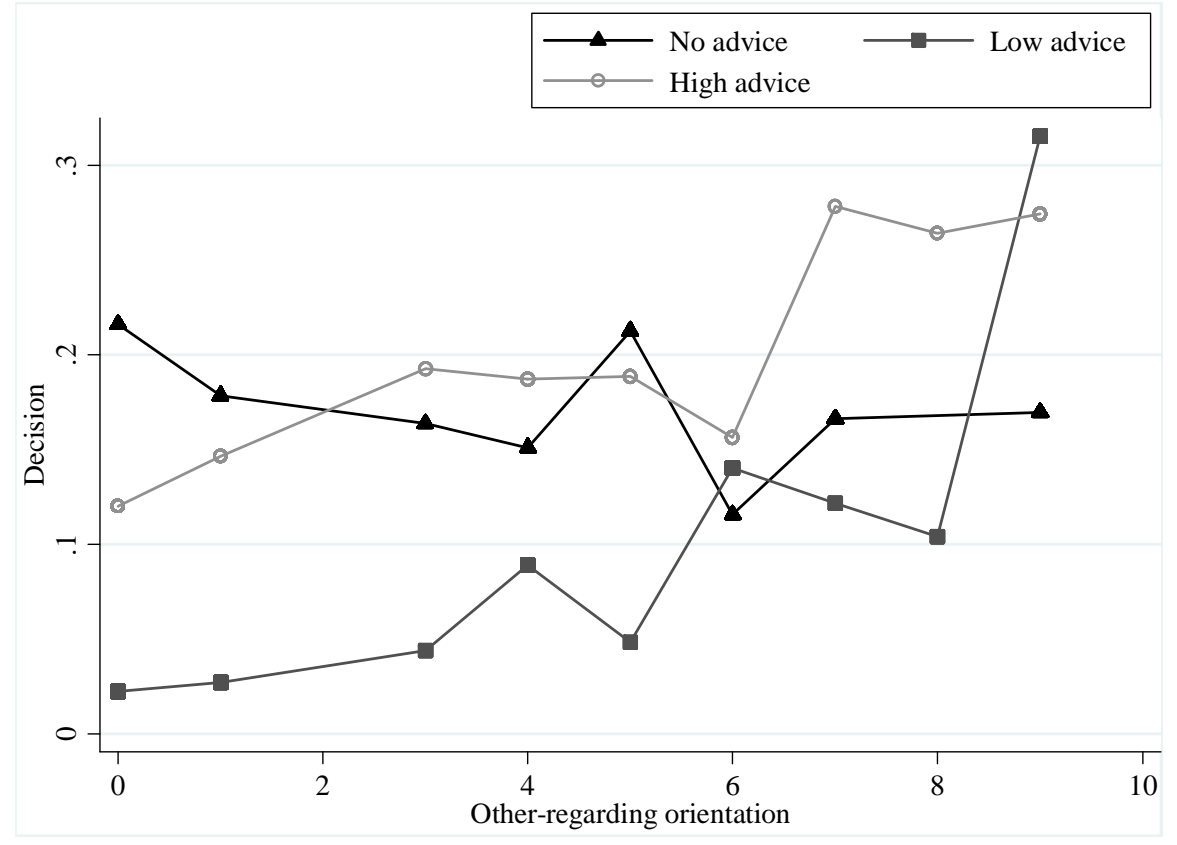

Figure 5. Interaction effect of orientation and advice received 


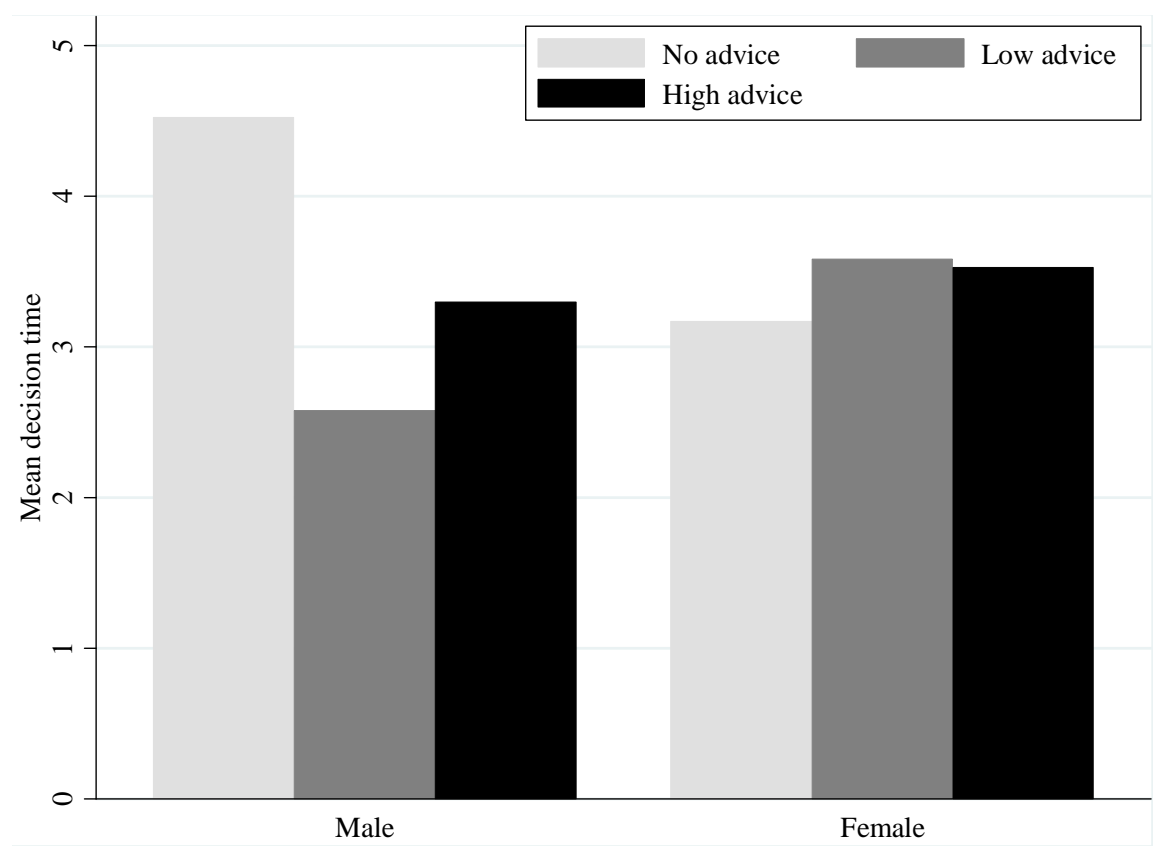

Figure 6. Interaction effect gender and advice received 